\title{
Marxist or Feminist Approaches to Sports Management Are There Traits in A Modern Days Society
}

\author{
Ian Arnott \\ Teesside Business School, University of Teesside \\ Middlesbrough, Tees Valley, TS1 3BA, UK \\ Tel: 44-1642-342-809Ｅ-mail: i.arnott@tees.ac.uk
}

\begin{abstract}
Many scholars have attempted to apply various theories in the field of sport (Bordieu, $1984 \&$ Brainer 2007). This particular area looks at the relationship between Marxism to the sociology of sport and how it has influenced societal structures as well as the impact it has had on the economy. Though these theories are useful on exploring the general nature of sport, questions may be raised on have they influenced the way sports is managed today also? It is widely accepted that management theories have been influenced by industry and that many scholars have used Marxism and feminist approaches to form some sort of construct of this. However does one or two apply to all? And are they appropriate to areas such as the service industry that sport falls in too? This paper attempts to look at how Marxism may have had some influence on sports management through capitalists, masculinity and power and the weld it has had on females developing in such a field because of its deeply held roots. And more importantly possibly oppressed feminism in this field. There are also arguments made because of such oppression by the male domination that they have used sports as a vehicle to segregate society and influence the direction of sports management.
\end{abstract}

Therefore the discussion in its true entirety at most is a snapshot of how one theory dominates the area of sports management and how it impinges on others both on their application and development.

Keywords: Marxism, Feminism, Power, Masculinity

\section{Conceptual approach to management in the field of sport}

The term management is often confused, overused, and interchanged with words like administration, operations, business, and corporation (Mull, Bayless and Jamieson, 2005). What firstly must be adhered to and addressed is that management processes and practices are not the same with in all industries. Most theory is based around industry (Mayo etc) in such directional approaches as scientific management or human relations (Mullins, 1993). But as society is changing then so are the approaches to management, especially as they are so diverse in nature and also so are their industries in what they offer both as they maybe product orientated or a service provider dealing with consumer's day I and day out. One such area is the field of sport, a sector that employs millions of people around the globe, is played and watched by the majority of the worlds population, and at the elite level, has moved from being an amateur past time to a significant industry or a full time profession (Hoye, Smith, Westerbeck, Stewart and Nicholson, 2006). What can be clearly evident from such a particular and diverse industry, are present traditional management concepts and theories applicable to the service sector such as sport? Is management (business) transferable to an area such like sport that caters for people and not products or vast heavy industries where theories have been developed? Also from a society where principles have been underlined from capitalism and capitalists. From approaches that in some cases have suppressed societies under such rule like that of Carl Marx? Have these concepts further gone onto allow other theories to develop because of such suppression and rule. Liu, Srivastava and Wood (1998) attempted to make some relationship between skills transference and theoretical conceptualisation. There theorising, though useful was to address issues about management and the implementation approaches to enhance productivity and operational procedures. They also drew on some of the work conducted by Peters (1996) in discussing how a peer could help an executive in coaching. Most of this theory draws upon partnership working and does not discuss in any great detail the application of theoretical frameworks in its true entirety to the field of sport. What arises from Liu et al's (1998) work that draws upon Peters (1996) is the application of how unique the nature of sport is. This is a view also shared by Smith and Stewart (1999) who indicate that sports management requires the application of specific management techniques. Therefore if business requires a similar approach it could be argued that Liu et al's (1998) skill transference may be applicable after all in sport? However business does not as Hoye et al (2006) leads us to believe encapsulates irrational passions for sporting teams, competitions, or athletes. Sport has a symbolic significance in relation to performance outcomes, success, and celebrating achievement that does not occur in other areas of economic and social activity (Shank, 2007). 
Furthermore sport and its management is a competitive human physical activity that is governed by institutional rules (Snyder and Spreitizer, 1989). A view further supported Vanderzwagg (1998) who concludes the management processes of sport requires many types of physical activity, utilising specialised equipment and facilities with unique dimensions of time and space. Therefore what can be clearly drawn out from this is that the nature of sport is physical. But if sport is governed by institutional rules that it could be argued that it has developed some of its approaches from capitalism, way of rules and governance? Key writers in sport such as Blain et al (1993) stresses this relationship between governance and rules in domains of sporting and political discourse, particularly as it relates to the construction of national, characteristics and identities such as physical prowess. So it could be argued from the constructs and the routes that sport has developed from there have been elements of capitalist and political control, so some elements of a Marxist regime. However what ever theorists stress about the nature of sport and its evolution a strong element of business must be applied to it as it has to be managed in some way, and more significantly during its evolution under rules, to give it direction to follow. Went is clearly felt that sport must follow a business like approach. Pitts, Fielding and Miller (1994) support this as they recall that for the management of sport to be successful it must be innovative and practioners must adopt a business enterprise approach in all its aspects for it to be successful. Therefore linking into Liu te al's (1998) ideology of the process of management being a skill and not the view shared by Vanderzwagg (1998) where it is seen as a physical form and displays power and the traits of masculinity

Whatever approach or conclusion maybe applicable, there most be some type of management theory linked or applicable to the service industry upon which the field sport is placed in. We can see that from its routes it could be argued that did sport and its management evolve as a way of controlling and industrialised society with capitalist approaches to segregate people? This then would suggest that Blain et al's (1993) view as a way of developing national characteristics and physical prowess (healthier and fitter workforce). What is clearly evident that society has developed and shaped some of these characteristics and may be better understood through academics and discourse analysis. What must be developed and understood are what are some of those characteristics that have shaped the management of sport? Is it what Blain et al (1993) explains a way of controlling, health, workforce, governance or ruling? And what has shaped the elements and characteristics to management with in a service sector field.

\section{Characteristics of the Service Sector similar to those shared by business through a societal change}

Hoye et al (2006) goes onto to share a view about the characteristics of the service sector, and is that they do carry distinguishing features similar to business and other management fields that draw upon management theories. He goes on to say, "Some of these features are such things as strategy, structure and human resourcing".

What now is clearly evident from this that the service sector and more importantly sport has some important function or feature, as it needs a management approach, way of control, strategy, systems. This could perpetuate to some of the ideas such as those previously highlighted under rule or characteristics with in those which have been previously highlighted Marxist (some type order)! or what Coackley (2004) links to, "conflict theory". A view on society as a system or social structures which are shaped by ultimately economic forces like no other, Similar to that described by Shank (2007) and also Beech and Chadwick,(2004) in describing sport. What must be denoted before addressing theoretical approaches that sport has evolved from an amateur paternal situation which was dominated in the post war era (Critcher, Bramham and Tomlinson, 2001). The sport industry in the United Kingdom is growing rapidly, though this is so, some may argue it does not always follow management principles and warrant proper discourse approaches. Where as, whilst it has not always been so properly understood, sports management has played an important role in society for years. As in some cases formed social order at various levels developing particular systems of control in society in the eastern world. This is why to some extent the argument can be made that those that control the nature, practices and development of sport weld considerable power (Henry and Lee, 2004)? Therefore is this a view that could be described as control? Or is masculinity coming through and a form of male domination.

This is similar to a view shared by Arnott (2007) who conducted research into the structure of swimming in the United Kingdom who identified through this that for sport to move forward, new management practices, theoretical approaches need to be implemented need by those who weld power (male centralisation). Therefore Whannel (1983) in writing argued because of such a hold and in some cases the key players resisting to new management practices can sport move forward? Whannel (1983) goes onto say that because of this resistance only in the last twenty years has the state (Government) played much of a role, where as in eastern societies it has been evident for a number of years.

In the United Kingdom the DCMS through a white paper passed through the government by the then Prime Minister Tony Blair wanted state intervention. By doing so under the guidance of Sport England the governmental advisor in sport, they did so through the Game Plan; a strategy for delivering governments sport and physical activity objectives (DCMS/ Strategy Unit, 2002). It made clear that local government, in dealing with societal issues will continue to be a major provider of sport. (Robinson, 2004). Because of the governments intervention strategy in sport and the management of it could be contextualised into similarities to an Eastern Block approach under the control of society or element s of Marxism as previously discussed? However the rationale for this provision for the state to provide sport is 
based on two arguments. First, there is the market failure argument; Local authorities provide sport for those who cannot afford the opportunities offered by other sectors (Robinson, 2004). Gratton and Taylor (2000) provide a comprehensive overview of the efficiency- and equity related reasons for public provision, however Coalter (1998) and Stabler and Ravenscroft (1994) highlighted the key motivation for the state provision is to ensure access for all citizens to sport opportunities through price subsidies and targeted programming. What ever argument is put forward it should be concluded that, Gratton and Taylor (2000) Coalter (1998) or Stabler and Ravesncroft (1994) it is clearly apparent from this that the state is beginning to dictate, what way is should be managed? Will every community seek to be managed in the same way and do they share the same motives? If so is the elements of Marxism on a societal approach appropriate to this aspect of sports management? The Department for Culture, media and Sport (DCMS)(1999) feel that sport improves, health, reduces crime, brings about economic improvement and improves educational needs and contributes towards lifelong learning similar to those views shared under that of a Marxist/ societal controlled environment a view shared by Sage (1998). Does the practioner with in this field feel that this is an appropriate way to manage sport? This approach to the management of sport it could be argued, that it shows a Marx (1969) approach where sport is managed by capitalists approach and where the workers are not allowed express themselves and work becomes not a satisfying experience within itself because there are limitations with in the processes that it is controlled. But under this type of management approach as it is suggested by the DCMS (1999) there are satisfying external outputs, such as a reduction in crime and lifelong learning. Then is this approach a necessity and do the external outputs seem to support this? More importantly will the British Culture, in principle, historically who disapproves of the state officially ' interfering' in the way people either spend free time or more importantly the way it should be managed. Thus through this type of practise regulate how the use of free time is made(Malcolmson, 1973 ; Bailey, 1973). However this has traditionally been the case where they have moreover utilised their paternalistic powers (Mcnamee, Sheridan \& Buswell, 2000). The British Governments approach to sports management is not only to its key policies, it is greater, because its what they believe is called the 'rationalisation of recreation'. There justification for this is what they believe is that they are providing facilities on the grounds of social justice, economy and control, illustrated by the proliferation of multi-purpose sports facilities under social welfare principles. They base there argument on this through the characteristics as one on 'socially enforced dependency' (Kultgen, 1991).

Boyle and Haynes (2000) in contrast to the writings s of that of Rojeck(1992) and Kultgen (1991) who describe socially enforced dependency, highlights that the characteristics of society as a pluralistic system, in which individuals choice is the key in determining the way and the pattern in which sport should be managed.

Boyles and Haynes (2000) look at sport management with a Marxist analysis, which posits the activities of management with in this discipline they are determined by the economic and political contours of society. In short sport and the way it is managed has become a vehicle of social control which both exploits workers and expanded the hold of capital on all areas, influencing human activity. With in the United Kingdom it could be argued under its current government, are they adopting a Marxist approach to the way sport is managed and are they beginning to classify what Coackly (2004) described a system of class? Have we gone the full circle from and industrial revolution? Some would say, "Is this a drastic view to take"?

This was something similarly that was experienced on the National Governing Bodies of Sport (change agents with in specific sports, e.g. swimming, cycling etc) in Canada between 1984 - 1988. Sport Canada, the governmental arm of sport with in this country stipulated that all sports NGB's had to take a more professional approach to the way they deal with things, but also must embrace some of the current issues in society (improvement of health etc) (Slack \& Hinnings, 1992, Macintosh \& Whitson, 1990).

With in the United Kingdom, the government (Department of Culture, Media and Sport) leads us to believe was a view similar to the Game Plan. This document indicated clearly the key performance indicators that all sports (NGB's) and local authority providers of sport had address social issues in their provision. The document highlighted how through social control (Marxist approach) that the way sport is managed would have cost benefits on dealing with societal issues but also enable such providers to tap into funding. So was this the only means that government could adopt. This was further exemplified by the then Chief Executive of Sport England at that time who indicated that for every pound that was invested in sport there would be multiple returns (Brooking, 2001). So it could be argued by forcing this approach to the way sport is managed that the government with in the United Kingdoms saw this as an approach or a resolution of the contradiction in a capitalist system. And with the improvement of health and improved education would this be a way improving the economy and increase production creates transformation (Haralambos \& Holborn, 2000). By using such vehicles/ tools is this furthermore a resolution to what we are already begin to see a run down society a fix to create ownership and put pride back into society. Whatever the case maybe a Marxist approach is one worth looking at with in the context of sports management. Horne, Jary and Tomlinson, 1987, p188) state that it; It allows us to understand power relations with in sport; it emphasises the role of the state and the economy in structuring sports management in a contemporary society; and it applies and open ended approach to studies so the new developments with in this field can be examined in a non-dogmatic fashion 
Rojeck (1992) recognises this as a "cultural studies" approach. It is useful because of its recognition of sport and the deeply rooted social processes involved hear. But he also attacks this approach as being too deterministic and overtly concerned with class and capital. What ever Rojeck (1992) indicates about the approaches is that it helps us to, though academic discourse understand the field of sports management. Further more Hargreaves (1994) and Creedon (1994) have highlighted the importance and understanding of gender relations in shaping sports management. By doing so this it enables not only the elements of Marxist theory of power relations, and societal change it underpins possibly some of the oppression towards females in this field and the underpinning of of some of the approaches adopted.

\subsection{Feminist theory has this helped to develop management approaches with in the field of sport?}

Feminist theories are grounded in the awareness that women have been systematically devalued and oppressed in many societies under power/ mascultinity sometimes underpinned by a Marxist approach (Coackley, 2003). But in the field of general management and more importantly on the bearing of this paper sports management, there is a general need to develop political strategies to eliminate oppression which developed from, what it could be argued is capitalism and capitalists. The yield to strive for power and economic growth contributed by a Marxist society? But it has been identified by many scholars that the area of sport today is state of economic and also contributes education, society and more importantly the economy. So if this is the case is there an argument to be said that different approaches and theories should be tested? Or is it the values and experiences that women have faced from men to celebrate their attributes and skills associated by masculinity in society (Birrell, 2000; Brurstyn, 1999) that will win through and never allow feminism to be tested. Though this is an expressed view shared by most feminist theorists (Hartman, 1981 \& Barrett, 1984) it must be acknowledged that the area itself is useful for discourse analysis and also a clearer understanding for some marginal attempt in the direction for the future of sports management. Gruneau (1999) shares this view also in the criticism of Marxist and Neo-marxist approaches and interpretations on the contextualisation of sports management that occupies Guttmans (1993) work with in this field.

Sport undoubtly has along tradition of gender order and how it has contributed to social relations in management, by elevating the male experience over females, in particularly in the powerful, hierarchical and visible way (Collins \& Kay, 2003). Therefore it could be argued as Collins and Kay (2003) describe has this been the key factor in the development of women in management and subsequently held back different views and theories of management with in the sports profession? Moreover because of a capitalist society dominated by males, elevating them to being the powerful gender in management, has this been a theoretical approach accepted dating back as far the industrial revolution. A case where the female's

responsibilities were affected by the growth and pressure to raise a family than in men's, which then particularly influenced a women's participation in sport when their household contained young children (Collins \& Kay,2005). Notably what can be derived from such pressures, the opportunity for females to even display femininity in sport management, never mind sport and its management? This notion of feminism in a way of a theoretical approach to management or the attractiveness and sexual availability to men in management is once again to keep them from seeking real power (Goldman et al, 1991). Connell (2002) supports this view where he describes that the hegemonic forms of masculinity as the "most honoured or desired with in this particular context and more specifically as the configuration of gender and the practices with in management. This further embodies the currently accepted answer to the problem of which theory is most applicable in the field of sports management, Marxist approaches or the opportunity for Marxist- feminists? This role within gender is further stressed that males are in a more dominant position with in management and females are still subordinate (Pringle \& Makula, 2005). Connells (2002) work was inspired by Gramsici's (1971) understanding that masculinity with actions of ruling classes or groups, economic activities and hierarchical structure of power, which demonstrates Marxism in management. The bases for this was from the industrialisations of the nineteenth century (Coventry, 2004), during a time that transformed the institution of work creating a paid labour force mostly male. Some Marxist - feminists have argued that a women's position in society primarily benefits capitalism and capitalists (Haralambos \& Holborn, 1991)? Some Marxists further believe that women benefit capitalists and its systems in their capacities as the mother and housewives, by producing the labour force at no cost to the employers (Hartman, 1981). This would further create a view that is it women or women in management? Or will they ever be able to achieve such positions to develop theories and approaches which clearly, what some might say "not the done thing"!

Dramatic reductions in sex segregation occurred in the 1970's, as women began to such what has already been demonstrated a male dominated occupations in management (Resking \& Roo's, 1990, Jacobs 1989; Beller, 1984). Although declines continued in the 1980's and 1990's, the pace of decline did become slower and slower (Padavic \& reskin, 2002; Bianchi,1995; Cotler et al, 1995; Jacobs, 1989). More recently Wenner (1989), Blain et al (1993), Whannel (1992) \& Goldhurst (1987) examined the role of some of these issues mediated in sport management and how it plays a form of symbolic ritual in many modern industrialised societies. They examined the transformation of sports management and argue that the study provides a particularly incisive insight into the commodoification of popular 
culture by capital (Boyle and Haines, 2000). So if this is the case then, even in sports management there is a clearer link to Marxist approaches and suppressing on an even bigger substantive scale stressing the view that feminists and feminist theories will struggle to prevail with in this field? Whannel (1997) argues that there is a need to be business like and efficient in sport and it offers sites for the celebration of corporate capitalism. And because of this political arguments are against feminism. Blain et al (1993) stressed this once again that even in the field of something that is still in its infancy the relationship between sport and political discourse, particularly as it relates to the constructs of management approaches and identities. What also was identified in the early 1990's was the first comprehensive national "women and sport policy" (Sports Council, 1993 and the Brighton Declaration, Sports Council, 1994 from an International conference).It explicitly recognised female under representation in sports organisations as a fundamental barrier to gender equity, and advocated greater women's involvement in all aspects and all levels of sports management (Collins \& Kay, 2004).. However, in sport elsewhere formal policies do not guarantee effective action, as McKay's (1997) in depth analysis of resistance to affirmative actions in sport organisations in Australia, Canada and New Zealand displayed.

To date Collins \& Kay (2004) demonstrate that policies to promote gender equity have too often floundered in the face of organisational and societal cultures where capitalism and capitalists instead of a move towards addressing a wider gender issues that are entrenched in society. An extensive debate around gender equity in sport which subsequently impacts their positioning in management positions, where many writers have argued that only through making fundamental changes in sport to lessen maleness and give pwer with in it, will women have true access to these positions which will in turn allow opportunity for appropriate theories to be applied.

Hardgrave's (1994), Kay, (1996); Mckay (1994) at the beginning of the new millennium, most men and women are still segregated into, different occupations. So are we capable of allowing female hierarchical positions to prevail?. Or is it the case that Marxist theory, especially in management, essentially in sport in this case is insignificant? Hartman (1981) compares the situation to marriage in which the husband represents Marxism, the wife feminism, and it is the husband who has all the power (the male).

Scholars have long recognised the manipulation of gender relations in management and culture as a function of capitalist hegemony (Artz \& Murphy, 2000). Women and girls have been what, Lynn, Hardin \& Walsdorf (2004) call symbolically annihilated (i.e rendered powerless). The notion of feminity attractiveness and sexual availability to men is used to keep women from seeking real power via feminism (Goldman et al, 1991). Goldman et al (1991) like Hartman (1981) re emphasises this nearly a decade later that this is a commercial marriage of a Marxist application of feminism and feminity. The reinforcement of sexual difference and the capitalism ideal where the women is primarily and ideally feminine is integral to the capitalists control (Lynn, Hardin \& Walsdorf, 2004).It also remind them that their power is only in their ability to maintain the ideal (Powerless) feminine body. These findings though there is an attempt to appraise Marxism and feminism in the management, and more relevant to this paper, sports management it is clearly evident that there are deeper roots of capitalism hegemony and gender roles with in sport today. That is sport is actively, and sometimes aggressively, contributes to the continual reproduction of the gender order and maintenance of masculine hegemony (Yiannakis \& Melnick, 2001) from a profeminist perspective sports are still viewed as reinforcing the sexual division of labour and also society. Therefore carrying Marxism approaches, and perpetuating inequality and society, and contributing to the exploitation of ruling classes and males to females (Kidd, 9187).

To be sure those capitalist views are relevant in this in this particular field that they are supported by the ideals outputs (economic, political and educational) and practices, but it is the ideology of patriarchy (e.g. structured and ideological) systems of personal relationships that legitimate male power over women and the services they provide(Sage, 1998) . That it helps and perpetuates for feminist theories and gender inequalities in sports management and the larger society (Yiannakis \& Melnik, 2001). The very construct of feminity and masculinity reinforce patricical culture. As long as males and females are looked at in this way males will continue to be viewed as dominant and females will also be subordinates. This will subsequently impact the opportunity for feminist theories to break through from some historical grounding developed from Marxist bedding.

\section{Conclusion}

This article has attempted to look at some of the approaches to management using two theoretical concepts, e.g. Marxists and Feminist theories. The concepts some might say are so far apart and the rationale for applying such frameworks to sport could not be further from the truth. Marxism with in sport, it is felt has some foundations from this approach. Bairner (2007) attempted to use such constructs in the sociological context of sport. He linked it to the "return of Marxism". Though his research is underpin by aspects of Bordieu (1984), their constructs link very much to management with in the context of sport and its progress. They draw upon the position of relations of production, such as occupation, income or even educational level, which bare very much the similarities to the Government with in the United Kingdom where as they see sport a contributor to this to a better society. A few that has also been discussed in Hargreaves (1986) writings of the link the relationship between civil society and the state in a way consistent to other 
scholars such as Gramsci (1971). So some might argue that there is possibly a place for Marxist theories in sports management? Which clearly will have an impact on the development of other theories such as feminist approaches? Gramsci (1971) in Bairner (2007) goes onto describe this further in the power relation between these two also. The term shared Yiannakis and Melnik (2001) in the recreation of the "gender order and the maintenance of masculine hegemony".

However Hartman (1981) believes that Marxism on its own cannot explain inequalities, in other words how much Marxism exploits capitalists, masculine hegemony and power in sports management as a form of social control, but not only how it exploits women. Hartman (1981) and Barrett (1984) accept that Marxism can play an important construct for gender in equalities, similar to that of King (2005) who refers to it as a "theoretical toolkit". However Collins and Kay (2004) provide some direction in explaining for other theories to break through and provide an application to management, essentially sport then there needs to be more women with in senior positions with in this field of study to allow more enquiries.

Whatever the long term outcome the most important thing to address is that the field of sports management is still growing and developing, and what has been clearly demonstrated general theories, though useful do not fully explain this area of study.

\section{References}

Arnott, I.R. (2007). An understanding towards organisational change in swimming in the United Kingdom. Paper submitted for part of the assessment process for a Doctorate in Business Administration.

Bailey, P. (1975). Leisure and class in Victorian England, J. Hargeaves, from social democracy to authoritarian populism: state intervention in sport and physical recreation in contemporary Britain, Leisure Studies, 4 (2), 219-226.

Bairner, A. (2007). Back to basics: Class, social theory, and sport. Sociology of Sport Journal, 24 (1) 20-36.

Barrett, M. (1984). rethinking women's oppression; A reply to Brenner \& Ramas New Left Review. Women's oppression today, London.

Beech, J \& Chadwick, S (2004) The Business of Sports Management Prentice Hall.

Beller, A.H. (1984). Trends in occupational segregation by sex and race, 1960-1981 In B.F , Reskin (eds) Sex segregation in the workplace: Trends, explanations, remedies. Washington DC: National Academy Press.

Bianchi, S. (1995). Changing economic roles of women and men.

Birrell, S. (2000). Feminist theories of sport In handbook of Sports Studies 61-76.

Blain, N, Boyle, R \& O Donnell, S. (1993). Sport and National Identity in the European Media. Leicester University Press.

Blanin, N Boyle, R. \& Odonnell, H. (1993). Sport and National Identity in the European Media. Leicester, Leicester University Press.

Bordieu, P. (1984). Distinction. A social critique of the judgement of taste. London: Routledge and Keegan Paul.

Boyle, R \& Haynes., R. (2000). Power Play, Sporty, the media and Popular Culture, Pearson education.

Coalter, F. (1998). Leisure Studies, Leisure Policy and social citizenship: the failure of welfare or the limits of welfare? Leisure Studies, 17 21-36.

Collins, M.F \& Kay, T. (2004). Sport and Social Exclusion, Routledge.

Connell, R.W. (2002). Masculinities and globalisation In Hworth, A., Paris, I \& Allen L (eds) The life of Brian masculinities, sexualities and health in New Zealand.

Cotter, D.Am, Defore, J.M, Hermsen, J $>$ M, Kowalewski, B.M \& Vannemun, R. (1995). Occupational gender desegregation in the 1980's, Social Scinece research, 24, 439-455.

Coventry, B.T. (2004). On the sidelines: sex and racial segregation in television sport broadcasting. Journal of Sports Sociology, 2 (3) 322-341.

Creedon, P. (1994). Women, Media and Sport,: Challenging the gender order. London, Sage.

Critcher, C., Bramham, P \& Tomlinson, A. (2001). Sociology of Leisure, A Reader, Spon, London.

DCMS/ Strategy Unit. (2000). Game Plan; A strategy for delivering the governments sport and physical activity objectives, London; Strategy Unit.

DCMS. (1999). Policy Action Team 10: Report to the social exclusion unit - arts and sport. London; HMSO.

Goldman, R, Heath, D \& Smith, S. (1999). Commodity feminism, Critical studies in media communication, 8, 333-351. 
Goldhurst, J. (1987). Playing for keeps; Sport the media and society. Melbourne Longman.

Gramsci, A. (1971). Selections from the prison notebooks In Hoare, Q \& Nowell- Smith, G (eds) London: Lawerence and Wishart.

Gratton, C \& Taylor, P. (2000). The Economics of Sport and Recreation, : London: E \& FN Spon.

Guttman, A. (1993). From ritual to record. The nature of modern sports. In Gruneau, A (eds) Class, sports and social development. Champaign IL, Human Kinetics.

Haralambos, M \& Holborn, M. (1991). The origins of gender inequality Marxist and social perspective. Sociology: Themes and perspectives $\left(3^{\text {rd }}\right.$ ed) pg 322-341.

Hargreaves, J. (1994). Sporting females.; Critical issues in the history and sociology of women's sport. London, Routledge.

Hargreaves, J. (1986). Sport, power and culture. A social and historical analysis of popular sports in Britain. Cambridge, UK: Polity.

Horne., J, Jary D \& Tomlinson A. eds (1987) Sport, Leisure and Social Relations. London : Routledge \& Keagan Pail.

Hartman, H. (1981). The unhappy marriage marxisim and feminism; Toward a more progressive union. In Segeant (eds) Capitalism, patriarchy and job segregation by sex.

Hoye, R, Smith, A, Westerbeck, G, Stewart, and Nicholson, M. (2006). Sports Management; Principles and Application, Butterworth and Heinemann.

Jacobs, J.A. (1989). Long term trends in occupational segregation by sex. American Journal of Sociology, 95, $160-173$.

Kay, T.A. (1996). Just do it? Turning sports policy into sport practice. Managing Leisure.

Kidd, B. (1987). Sports and Masculinity. In Kaufman (eds) Beyond patriarchy: Essays by men on pleasure, power and change. New York; Oxford University Press, 250-265.

Kings, C.R. (2005). Cautionary notes on whiteness and sports studies. Sociology of Sport Journal, 22 (1) $397-408$.

Kultgen, J. (1991). Ethics and Professionalism, Philadelphia, University of Pennsylvania Press.

Liu, T., Sirvastave, A \& Seng Woo, H. (1998). Transference of skills between sports and business, Journal of European Industrial Training, 22 (3) 93-112.

Lynns, S, Hardin, M \& Walsdorf, K. (2004). Selling (out) the sporting woman; Advertising images in four athletic magazines. Journal of Sports Management, 18 (4) 335-349.

Macintosh, D \& Whitson, D.J. (1990). The game planners transforming Canada's sport system. Montreal \& Kingston: McGill-Queen University Press.

Malcolmson, R. (1973). Popular recreations in English society, J. Hargeaves, from social democracy to authoritarian populism: state intervention in sport and physical recreation in contemporary Britain, Leisure Studies, 4 (2), $219-226$.

Marx, K. (1969). The Notion of Alienation, in Mullins, L.J (1993) Management of Organisational Behaviour (4 ${ }^{\text {th }}$ Ed) Pitman Publishing.

Mckay, J. (1997). Managing gender: Affirmative action and organisational power in Australian, Canadian and New Zealand Sport, Albany NY: Stat University of New York Press.

McNamme, M.J, Sheridan, H \& Buswell, J. (2000). Paternalism, Professionalism and public sector leisure provision: the boundaries of a leisure profession. Leisure Studies, 19,199-209.

Mull, R.F, Bayless, K.G \& Jamieson, L.M. (2005). Recreational Sport Management (4 ${ }^{\text {th }}$ ed) Champaign IL, Human Kinetics.

Mullins, L. J. (1993). Management and Organisational Behaviour (4 ${ }^{\text {th }}$ ed), Pitman Publishing.

Padavic, I \& Reskin, B. (2002). Women and men at work $\left(2^{\text {nd }} \mathrm{ed}\right)$ Thousands Oak, CA.

Peters, H. (1996). Peer Coaching for Executives; Training and development, Vol 50. pg 39-42.

Pitts, B.G, Fielding, L.W \& Miller, L.K. (1994). Industry Segmentation theory and the industry; developing a sport industry segmentation model. Sports Marketing Quarterly; 3 (1) 15-24.

Pringles, R \& Markula, P. (2005). No pain in sane after all: A foucaualdian analysis of masculinities and men's experiences in rugby. Sociology of Sport Journal, 22 (4) 472-497.

Reskin, B.F \& Roos, P.A. (1990). Job queues, gender queues; explaining women's movement into male dominated occupations. Philadelphia: Temple University Press. 
Rojeck, C. (1985). Capitalism and Leisure Theory, London Routledge- (1992) The Field of Play in Sport and Leisure Studies. In Dunning E, Rojeck., C (eds) Sport and Leisure in the Civilising Process.

Robinson, L. (2004). The public sport and leisure context; Managing Public Sport and Leisure Services. Routledge.

Slack, T \& Hinnings, B. (1992). Understanding Change in National Sport Organisations; an integration of theoretical perspectives; Journal of Sport Management. (6), 114 -132.

Stewart, B., and Smith, B. (1999). Sports Management; a guide to professional practise, Sydney, Allen and Unwin.

Snyder, E.E and Spreitzer, E.A. (1989). Social Aspects of Sport, Englewood Cliffs, Prentice Hall.

Vanderzwagg, H.J. (1998). Policy Development in Sport Management $\left(2^{\text {nd }}\right.$ ed) West Port, CT Praegar.

Wenner, L.A. (1998). Playing the media sport game. In media sport (Wenner L.A ed) London, Routledge.

Whannel, G. (1992). Fields of vision, Television Sport and Cultural Transformation. London, Routledge.

Whannel, G. (1983). Blowing the Whistle, Pluto Press, London. 